\title{
Development of Universal Skills at the Russian Universities: Challenges and Experience
}

\author{
Svetlana D. Ahmetova ${ }^{1 *}$, Larisa $V$. Nevskaya $^{1}$, and Irena A. Esaulova ${ }^{1}$ \\ ${ }^{1}$ Perm National Research Polytechnic University, Russia
}

\begin{abstract}
Rapid technological development and digital transformation in all areas of life have resulted in a dramatic change in the nature of thinking and requirements to skills. In the information economy, it is not money or natural resources, or territory but people with their critical thinking and high-quality skills, who have become a valuable asset. In this regard, the educational sector advances to the forefront. However, education hardly complies with the requirements of the new economy and retains its basic features of the industrial era. The curricula and educational processes at universities fail to prepare young people for life in our complicated world, or develop critical thinking; they discourage creativity and ability to cooperate. Curricula tend to focus on the development of professional skills and neglect the development of social and cognitive skills. The study sets out to investigate the usefulness of higher social and cognitive skills in the educational process at the Faculty of Humanities in Perm National Research Polytechnic University and offers recommendations on the development of these skills in the educational process.
\end{abstract}

\section{Literature review}

One of the main obstacles to economic development in many countries, including Russia, is the problem of shortage of professional and transferable skills. The research by McKinsey Institute states that 375 million workers in the world may have to change their profession within the next decade [1].

McKinsey's new global survey of future workforce needs claims that nearly nine out of ten executives and managers identified skill gaps in the workforce. [2] Though most respondents prioritized tackling skills shortages, only a few demonstrated the understanding of how to ensure the acquisition of new skills by employees.

The report "Automating Skill Changes and the Future of the Workforce" by Mackenzie Institute [3] presented the evolution in skill categories and changes in worked hours. The following skill categories were identified:

- Physical and manual skills;

- Basic cognitive skills;

- Higher cognitive skills;

- Technological skills;

* Corresponding author: sgahmetova@gmail.com 
- Social and emotional skills.

The skill evolution was calculated with CAGR from 2004 to 2016, extrapolated to 14 years based on the difference between hours worked per skill in 2016 and simulated hours worked in 2030. The evolution in skill categories is presented in Figure 1.

Automation of processes across all industries will inexorably lead to some jobs disappearing, or main tasks and job responsibilities adjustments. Consequently, the requirements for job skills should be revised.

The role of high cognitive skills, namely the ability to make non-standard decisions, or solve emerging problems, or plan work tends to constantly improve.

The role of social and behavioral skills, i.e. leadership skills, the ability to work independently, and to collaborate with the team becomes more important.

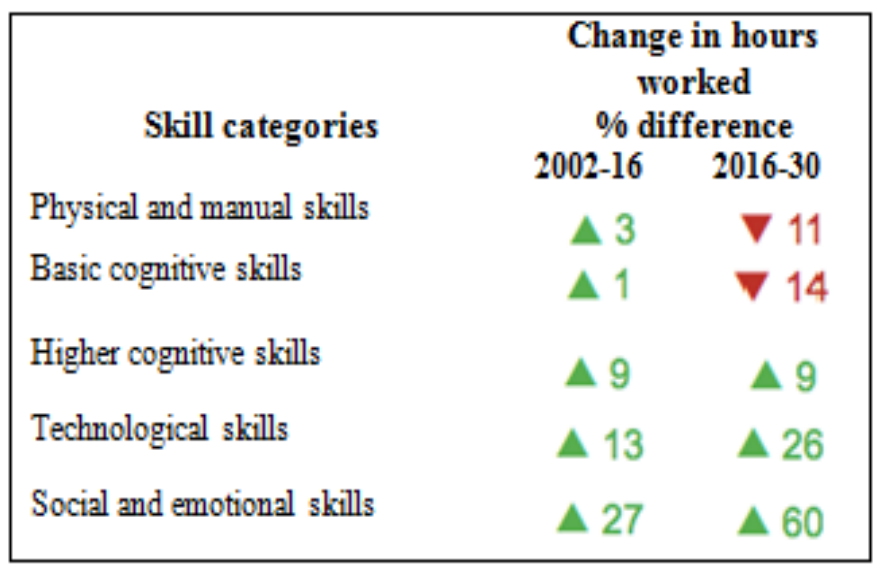

Fig. 1. Evolution in skill categories.

The concepts of high social and cognitive skills are often referred to as soft skills or universal skills by researchers. Of all others, they empower the effective development of professional and other specific skills.

Social and cognitive skills are defined by researchers as soft skills or universal skills. Technologies develop so rapidly that knowledge quickly becomes obsolete that leads to the heightened demand in universal skills applicable in various professional fields. They are universal skills that facilitate further development of professional and other special skills.

Technological skills. Most of the activities in the digital economy are highly technology-dependent. In concurrence, the key problem is the need to integrate these skills in the relevant field of activity. For example, real estate managers should be able to use information systems to identify trends in sales and prices in different areas; welders have to be able to use robots in the process of pipe repair; doctors - to analyze MRI, etc. In the digital transformation of business, the importance of these skills is significantly increasing. Today, the ability to build successful communication using new technologies in companies' distributed work environments is crucial. The new technologies contribute to an easier and less painful transition to the telework format in case of a crisis.

In early 2020, LinkedIn analysts conducted a global survey among 1,675 HR professionals, 2,000 students, and 2,932 managers responsible for the introduction of educational technologies. The results of the survey were published in a corporate education market annual report [4]. The study revealed that universal skills are the foundation of success for any employee, regardless of their position.

L\&D-specialists claim that the priority is given to leadership and management programs, the development of creativity and design thinking, and communication skills. 
The students also confirmed their desire to develop universal skills. This is especially true for millennials and generation X, as many of them plan to become managers or executives. The survey also found that almost $80 \%$ of learners, regardless of generation, would like to receive personalized training based on their career goals and skills required in digital world.

Over the next 10 years, many organizations will be redesigning workplaces due to the emergence of intelligent machines, robots, chatbots, freelancers.

John E Marthinsen, professor of economics and international business at Babson College, cited several reasons for the gap between the skills managers need and the skills managers have [5]:

- Baby Boomers who have knowledge and expertise retire en masse;

- Technological advances require new skills in the labor market, and educational systems struggle to keep up;

- The global competition puts companies under additional pressure for new talents;

- The quality of education in the US is excellent but business leaders understand that other countries have advantages and are moving faster;

- There are fewer opportunities to invest in training and retraining of employees compared to the past, as frequent talent transfers reduce the return on investment in education.

The given reasons are typical for many companies in different countries, including Russia. A study by the World Bank and the Higher School of Economics [6] confirmed that Russian companies, especially innovative ones, desperately need employees with high cognitive and social skills but the education system does not guarantee adequate development. The gap between necessary and available skills has appeared due to the mismatch between education and the labor market both in Russia [7] and abroad [8]. Russian universities are focused on the development of basic skills and disregard the demand of employers for high cognitive skills, social, and behavioral skills.

At the EduTech seminar of the Sberbank Corporate University, Elena Kazakova, director of St. Petersburg University Institute of Pedagogy, claimed that the main problem of the transition of the modern society to the post-industrial phase was the lack of understanding of the urgency to restructure the educational system by the leadership [9]. Further development of universities, in her opinion, depends on their ability to adapt to new conditions. The fact that mass public educational systems are completely unsuitable for the 21 st century changed conditions was confirmed by Ken Robinson, the British education expert, in his book "School of the Future" back to 2015 [10].

The study by Boston Consulting Group revealed that higher education in Russian has become massive though it has lost in quality [11]. Meanwhile, the majority of employers detect the lack of practical knowledge among graduates. A study by the Institute of Demography of the Higher School of Economics showed that almost $30 \%$ of employees with higher education deny the connection between the work they do and the professional knowledge they acquired at the university [12].

A study conducted by the Organization for Economic Cooperation and Development (OECD) and WorldSkills, with the participation of Education and Employers, showed that $44 \%$ of young people anticipate that their skills and knowledge will not be marketable [13]. By the World Bank and the Russian National Research University Higher School of Economics (HSE), 29\% of students do not know what they will do after graduation; 7\% of graduates continue their studies.[14].

In the 21 st century, skills become obsolete faster than the standard period of study, therefore new skills have to be included in educational programs. In 2002-2010, Partnership for 21st Century Skills (P21), the American non-profit association, developed a model of 
"Four Cs" skills: critical thinking, communication, collaboration, and creativity. These skills constitute the core set of soft skills.

In recent years, the new educational standards of Russian universities have included a set of universal competencies to develop high social and cognitive skills. However, the new set of universal skills cannot be incorporated into the existing educational process without changing the way of transferring knowledge, and training skills [15]. Therefore, educational processes at many universities do not develop marketable skills.

The article is aimed to study the conditions for the formation of universal skills in the educational process at universities and develop recommendations for its improvement.

\section{Methodology}

The paper is based on Russian and foreign literature sources and research in the field of education. The methods of comparative analysis and synthesis are applied in the current study. Today, the main aim of research into universal skills is to identify the problems of education that hinder their formation.

In the study, the authors aimed to accomplish the following tasks:

1. Students' understanding of new skills value;

2. The focus of educational programs on developing new skills;

3. Teaching methods and educational technologies aimed at the formation of new skills.

The research was conducted at the Humanities Faculty of Perm National Research Polytechnic University (PNRPU). The study involved 180 students and 45 teachers.

\section{Results}

A questionnaire was developed to evaluate the students' understanding of the social and cognitive skills concept.

The results of the survey are presented in Figure 2.

As the research states, the majority of students are not familiar with the concept of "high social and cognitive skills." However, they consider the skills included in the concept significant for their future professional activity.

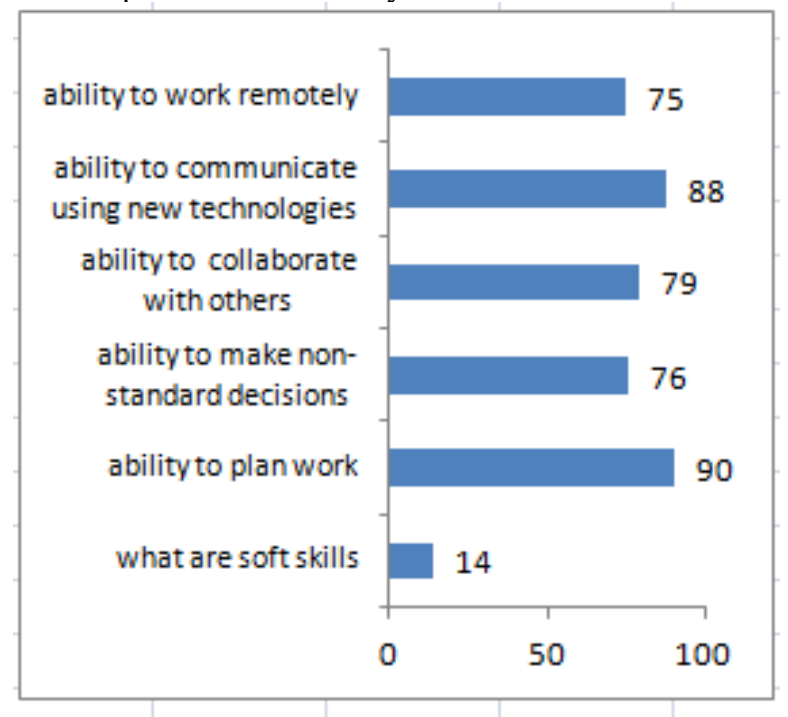

Fig. 2. Results of the students' survey (ratio of positive answers to all participants). 
These results share similarities with studies conducted at the South Ural State Humanitarian Pedagogical University [16] and Moscow State Institute of International Relations [17].

The educational standard for training Bachelor of Management Studies Degree students at PNRPU includes profile disciplines focused on the development of universal skills (Fig. 3).

\begin{tabular}{|c|c|c|c|c|c|c|}
\hline \multirow[b]{2}{*}{ Soft skills } & \multicolumn{6}{|c|}{ Profile disciplines in which these skills are formed } \\
\hline & $\begin{array}{l}\text { Digital } \\
\text { Techno } \\
\text {-logies }\end{array}$ & $\begin{array}{l}\text { Project } \\
\text { Manag } \\
\text { ement }\end{array}$ & $\begin{array}{l}\text { Leaders } \\
\text { hip }\end{array}$ & $\begin{array}{l}\text { Organiza } \\
\text { tional } \\
\text { Behavior }\end{array}$ & $\begin{array}{l}\text { Strategic } \\
\text { Manage } \\
\text { ment }\end{array}$ & HRM \\
\hline Leadership & & & & & & \\
\hline Cooperation & & & & & & \\
\hline Communication & & & & & & \\
\hline Digital skills & & & & & & \\
\hline Critical thinking & & & & & & \\
\hline Teamwork & & & & & & \\
\hline Creativity & & & & & & \\
\hline
\end{tabular}

Fig. 3. Profile disciplines and universal skills.

Thus, almost all key disciplines concentrate not only on gaining professional knowledge but also on the formation of universal skills. Though the task remains challenging or even insoluble to achieve using only traditional teaching methods: lectures, seminars, practical exercises. The previous findings [17, 18] confirm the importance of digital skills that are prerequisite for studying major disciplines in a program.

Developing creativity cannot be based on traditional assignments and tests. Teaching collaboration cannot be realized without doing projects and case studies. The traditional learning environment does not have room for models and tools based on new information technologies.

On the other hand, a digital learning environment facilitates the application of new models and tools for exchanging information, developing effective communication, and doing group projects. The most effective models for developing universal skills are the BYOD (Bring Your Own Device) model and a flipped classroom model. Unfortunately, a digital platform does not always ensure the use of new models for the formation of universal skills.

In 2018, the authors conducted a study to identify the reasons for the insufficient use of the Portal and new teaching models by teachers at their department [19]. The results highlighted that the reasons are the high workload, the complexity of working at the Portal, the lack of skills, and the ability to work with IT. Moreover, almost $40 \%$ of professors considered traditional teaching technology quite sufficient for achieving educational goals. This year a follow-up survey presented similar results. 


\section{Conclusion}

The authors consider that the attitude to the traditional educational process will change only if educators start to actively use educational platforms that almost all Russian universities have. The digital environment (educational platform) is a toolkit for the development and implementation of innovative educational technologies. This will lead professors to the acquisition of new competences and students to be able to work independently.

These innovations are closely connected with interactive learning that prepares students for life in a dynamic and constantly evolving digital society. New knowledge appears every day, and therefore the need for mastering new skills is continually increasing. Students who grow up in a digital society regard digital platforms as a safe and friendly environment and work on them is a natural extension of communication with their peers on social networks.

This work tends to be more complicated for their professors.

Working at the Portal is time-consuming and requires appropriate motivation, including financial. Unfortunately, at present, whether a professor adjusts educational materials for posting on the Portal depends entirely on their internal motivation. The problem of motivating educators to use innovative technologies in teaching is urgent and requires making decisions on the higher level of the education system.

The second problem, as the current research has shown, is connected with the insufficient digital competence of many professors. Many of them are highly qualified specialists but they cannot post their educational, methodological, and test resources on the Portal, or organize online communications with their students.

In 2019, the authors founded an E-competence Center. Such centers successfully function in many Western universities. Centers council professors and lectures on how to publish the content of the discipline (educational, methodological, and test resources) on the Portal, how to organize communication, and introduce new learning models to form universal skills. Consulting is carried out both in face-to-face and online formats. For online mode, there is a "Teacher's Page" with a forum that gives recommendations on the use of portal tools.

Though the Center began its work not long ago, some results have already been achieved. About $30 \%$ of the teachers at the department, who realize the need to switch to new technologies and models, have created their pages on the Portal. This was facilitated by the need to change to a distance learning format during the quarantine period. Currently, the teachers are updating their pages using new portal tools and introducing new models in the educational process.

\section{References}

1. Mckinsey Global Institute (2015). URL: https://www.mckinsey.com/featuredinsights/future-of-work/jobs-lost-jobs-gained-what-the-future-of-work-will-mean-forjobs-skills-and-wages

2. Mckinsey Global Institute (2019). URL: https://www.mckinsey.com/featuredinsights/mckinsey-global-surveys

3. Automation and future of the workforce. Mckinsey Global Institute. (2018). URL: https://www.mckinsey.com/featured-insights/future-of-work/skill-shift-automationand-the-future-of-the-workforce\#

4. Workplace Learning Report (2020). URL:

https://learning.linkedin.com/resources/workplace-learning-report

5. L. Dixon. Is the Skills Gap Real? (2017).

URL:https://www.chieflearningofficer.com/2017/07/21/skills-gap-real/ 
6. Developing skills for innovative growth in Russia. World Bank and NRU HSE (2015).

7. S. Roshchin, V. Rudakov, Do the starting salaries of graduates measure the quality of education? Review of Russian and Foreign Studies // Education Issues. No. 1. P. 138168 (2015).

8. F. Caroleo, F. Pastore, Overeducation at a glance. Determinants and wage effects of the educational mismatch based on AlmaLaurea data. GLO Discussion Paper, Series 15. Geneva: Global Labor Organization (GLO) (2017).

9. EduTech of Sberbank Corporate University (2020).URL:https://edutechclub.sberbankschool.ru/all/edutechpulse13/

10. K. Robinson,, L. Aronica, Creative schools. New York: Viking (2015).

11. Russia 2025: From Personnel to Talent (2017).URL:http://d-russia.ru/wpcontent/uploads/2017/11/Skills_Outline_web_tcm26-175469.pdf

12. E.Varshavskaya, Where and by whom do highly educated Russians work (2017). URL: http://www.demoscope.ru/weekly/2017/0713/tema06.php

13. OECD Forum (2019). URL: https://www.oecd-forum.org/users/264950-nickchambers/posts/53006-young-people-don-t-feel-ready-for-the-future-of-work

14. Skills development for innovative growth in Russia, Report No. ACS1549. World Bank and NRU HSE (2015).

15. Skills of the future. What you need to know and be able to do in a new complex world. Global Education Futures and WorldSkills Russia (2017).

16. A. Savchenkov, N. Uvarina, Professional stability as a key "soft skills" of a teacher. Bulletin of the Mari State University. .Vol. 13. No. 3.P. 375-382 (2019).

17. L. Raitskaya,, E. Tikhonova, Soft skills in the view of teachers and students of Russian universities in the context of world experience // Bulletin of the Peoples' Friendship University of Russia. Series: Psychology and Pedagogy. Vol. 15. No. 3.P. 350-363 (2018).

18. L.Nikitina, F. Furuoka, Sharp focus on soft skills: a case study of Malaysian university students' educational expectations. Educational Research for Policy and Practice, 11, 207-224 (2012)

19. S. Akhmetova, L. Nevskaya, Formation and Development of Skills in the Learning Process of the Digital Age // IDIMT-2019. Innovation and Transformation in a Digital World: 27th Interdisciplinary Information Management Talks, Sept. 46, 2019, Kutna Hora, Czech Republic / Ed .: P. Doucek, G. Chroust, V. Oskrdal, Johannes Kepler Universitat Linz. - Linz: Trauner Verlag, - P. 143-151 (2019). (Schriftenreihe Informatik 48)., Scopus. 